\title{
A study on the relationship between emotional intelligence, organizational commitment and organizational citizenship behavior
}

\author{
Saman Chehrazi $^{\mathrm{a}^{*}}$, Mehrdad Hoseini Shakib ${ }^{\mathrm{b}}$ and Mohammad Hosein Askari Azad ${ }^{\mathrm{a}}$
}

${ }^{a}$ Department of Industrial Enginneering, South Tehran Banch, Islamic Azad University, Tehran, Iran ${ }^{b}$ Department of Industrial Enginneering, Karaj Banch, Islamic Azad University, Tehran, Iran

\begin{tabular}{|c|c|}
\hline CHRON I C LE & ABSTRACT \\
\hline $\begin{array}{l}\text { Article history: } \\
\text { Received December 2, } 2013 \\
\text { Accepted } 8 \text { May } 2014 \\
\text { Available online } \\
\text { May } 192014 \\
\text { Keywords: } \\
\text { Emotional intelligence } \\
\text { Organizational citizenship } \\
\text { behavior } \\
\text { Organizational commitment }\end{array}$ & $\begin{array}{l}\text { This paper presents a casual structure model between emotional intelligence and organizational } \\
\text { citizenship behavior by using organizational commitment as mediator variable. The study is } \\
\text { accomplished among } 324 \text { employees of united bus company in city of Tehran, Iran. Using } \\
\text { structural equation modeling, the study has confirmed that emotional intelligence influenced on } \\
\text { organizational citizenship behavior and commitment. The study also confirms that } \\
\text { organizational commitment influenced on organizational citizenship behavior. Finally, the } \\
\text { study has confirmed that there were significant relationships between emotional intelligence } \\
\text { and its dimensions with organizational citizenship behavior and organizational commitment of } \\
\text { employees. }\end{array}$ \\
\hline
\end{tabular}

\section{Introduction}

During the past few years, there have been tremendous efforts on learning the effects of various factors on organizational commitment (OC), organizational citizenship behavior (OCB). Emotional intelligence (EI) is believed as one of the most important issues affecting on employees' commitment. Khalid et al. (2009) investigated the effect of personal factors, EI and OCB on deviant behaviors using the data taken from 263 undergraduate business students from a public university located on the northern region of Peninsular Malaysia. They reported that sportsmanship and EI significantly and negatively associated with deviant behaviors. The results also indicated that male students and those with lower academic achievement had substantially higher level of deviant behaviors. Kim et al. (2005) examined the relationship between employee service orientation including customer focus, organizational support, and service under pressure and employees' job satisfaction, OC, and employees' intention of leaving by developing a structural equations modeling framework. They reported that the customer focus of employees was negatively related to employees' job satisfaction, *Corresponding author. E-mail addresses: samanchehrazi@gmail.com (S. Chehrazi) 
but positively related to their organizational commitment. In addition, organizational support influenced positively on job satisfaction and job satisfaction was positively associated with OC. Jain (2009) examined the predictive capability of OCB and EI with regard to organizationally relevant criteria including job satisfaction, personal effectiveness, reputational effectiveness, etc. They reported that OCB was a powerful predictor of organizationally relevant criterion variables. Kondratuk et al. (2004) evaluated the relationship between career mobility history and a recent internal or external job change on OC using Meyer and Allen (1991) three-dimensional model. In this survey, they reported that external career mobility history was negatively associated with normative commitment, but not to affective and continuance commitment. Affective and continuance commitment were substantially lower for external movers prior to a move when compared with nonmovers over the same time.

\section{The proposed study}

This paper presents a casual structure model between emotional intelligence and organizational citizenship behavior by using organizational commitment as mediator variable. The study is accomplished among 600 employees who worked for united bus company in city of Tehran, Iran. The sample size is calculated as follows,

$n=\frac{N \times z_{\alpha / 2}^{2} \times p \times q}{\varepsilon^{2} \times(N-1)+z_{\alpha / 2}^{2} \times p \times q}$,

where $N$ is the population size, $p=1-q$ represents the yes/no categories, $z_{\alpha / 2}$ is CDF of normal distribution and finally $\varepsilon$ is the error term. Since we have $p=0.5, z_{\alpha / 2}=1.96$ and $N=600$, the number of sample size is calculated as $n=320$. The study is accomplished among 324 employees of united bus company in city of Tehran, Iran. The study uses a standard questionnaire developed by Bradberry and Greaves $(2004,2006,2009)$ for measuring emotional intelligence, which maintains four perspectives with 28 questions. For measuring organizational commitment, the study uses another standard questionnaire developed by Meyer and Allen (1991) with 3 dimensions and 24 questions. Finally, the study uses a standard questionnaire developed by Podsakoff et al. (2000) with 5 dimensions and 20 questions. Cronbach alphas for emotional intelligence, organizational commitment and organizational citizenship behavior have been calculated as $0.937,0.938$ and 0.934 , respectively, which are well above the minimum acceptable level of 0.7 . The study considers the following three hypotheses,

1. Emotional intelligence influences positively on organizational citizenship behavior.

2. Emotional intelligence influences positively on organizational commitment.

3. Organizational commitment influences positively on organizational citizenship behavior.

The study uses structural equation modeling in order to examine the hypotheses of this survey. Fig. 1 shows details of the personal characteristics of the participants.

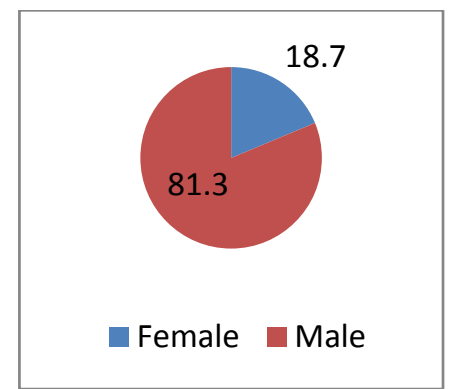

Gender

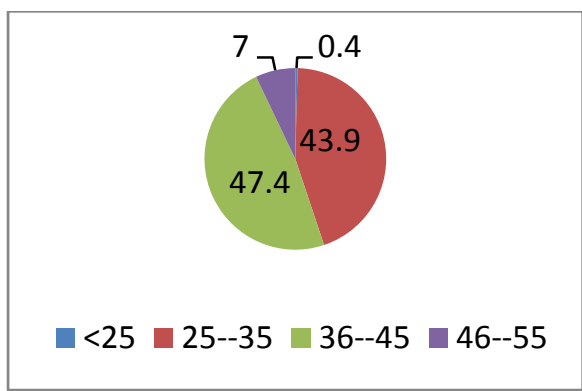

Age

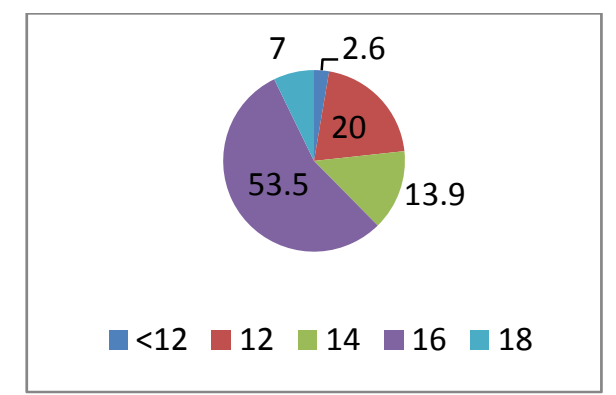

Years of education

Fig. 1. Personal characteristics of the participants 
In our survey, most participants were middle-aged male and they hold some university educations. In addition, nearly, $90 \%$ of the participants had at least five years of job experiences. KolmogorovSmirnov test has been applied to verify the normality of survey and Table 1 summarizes the results of our survey.

\section{Table 1}

The results of Kolmogorov-Smirnov test on three components of the survey

\begin{tabular}{lccccc}
\hline Variable & Number & Mean & Standard deviation & K-S & Sig. \\
\hline Emotional intelligence & 230 & 100.17 & 16.94 & 0.636 & 0.813 \\
Organizational citizenship behavior & 230 & 71.95 & 13.3 & 0.712 & 0.691 \\
Organizational commitment & 230 & 83.39 & 14.79 & 0.784 & 0.976 \\
\hline
\end{tabular}

As we can observe from the results of Table 1, all components of the survey are normally distributed when the level of significance is five percent. Therefore, we may use parametric test to verify the hypotheses of the survey. The implementation of t-value test on Emotional intelligence, Organizational citizenship behavior and Organizational commitment are 14.51, 11.60 and 13.68, respectively and they all meaningful when the level of significance is one percent.

\section{The results}

In this section, we present details of our findings on testing different hypotheses of the survey based on the implementation of structural equation modeling. Fig. 2 shows details of our findings,

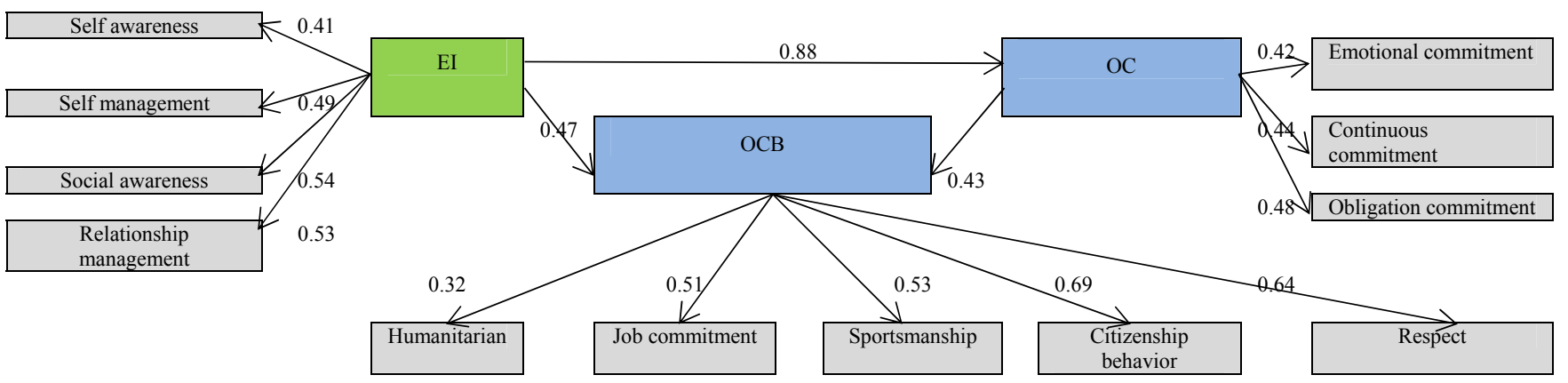

Fig. 2. The results of standard coefficients

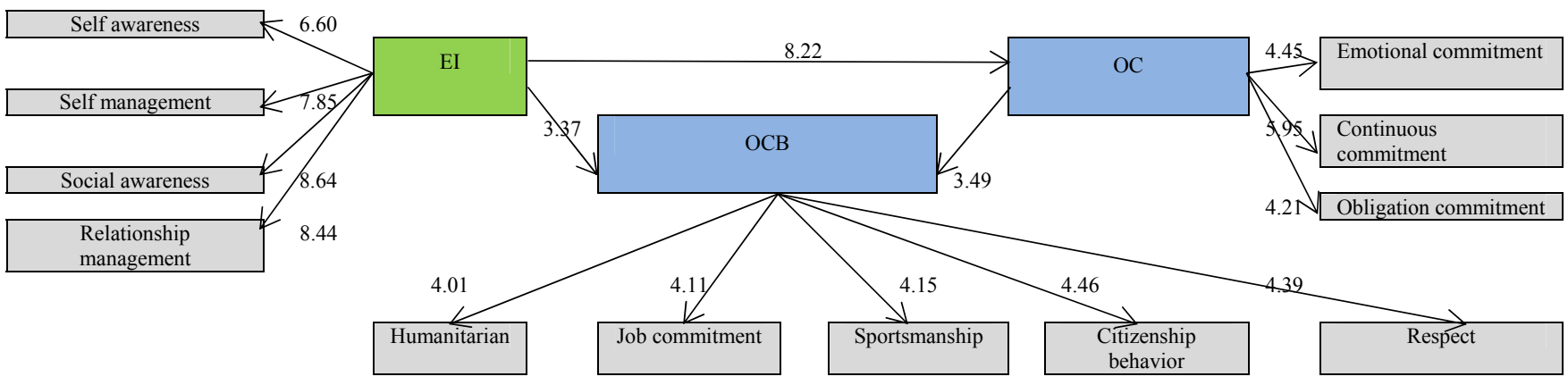

RMSEA $=0.011$ Chi-Square $=52.3 \mathrm{GFI}=0.96 \mathrm{CGI}=0.99$

Fig. 3. The results of t-value coefficients

As we can observe from the results of statistical observations such as t-student values as well as RMSEA and Chi-Square values, all statistical observations are meaningful when the level of significance is one percent. In addition, the relationships among different components are positive, which verifies all hypotheses of the survey. 


\section{Conclusion}

In this paper, we have performed an empirical investigation to study the effects of emotional intelligence on organizational commitment as well as organizational citizenship behavior in a publication transportation organization in city of Tehran, Iran. The study has confirmed that emotional intelligence influences positively on organizational commitment $(\beta=0.88$, P-Value $=$ $0.000)$. In addition, organizational intelligence influences on organizational citizenship behavior positively $(\beta=0.47$, P-Value $=0.000)$. Finally, organizational commitment influences on organizational citizenship behavior $(\beta=0.43$, P-Value $=0.000)$. The results of the survey are consistent with findings of Farh et al. (2004), Kirkman and Shapiro (2001), Kim (2006), Brief and Motowidlo (1986) and Paine and Organ (2000).

\section{Acknowledgement}

The authors would like to thank the officials of public transportation organization for cordially cooperating in this survey.

\section{References}

Bradberry, T., \& Greaves, J. (2004). Emotional intelligence appraisal: There is more than IQ. TalentSmart.

Bradberry, T., \& Greaves, J. (2006). The emotional intelligence quick book: Everything you need to know to put your EQ to work. Simon and Schuster.

Bradberry, T., \& Greaves, J. (2009). Emotional Intelligence 2.0. TalentSmart.

Brief, A. P., \& Motowidlo, S. J. (1986). Prosocial organizational behaviors.Academy of management review, 11(4), 710-725.

Farh, J. L., Zhong, C. B., \& Organ, D. W. (2004). Organizational citizenship behavior in the People's Republic of China. Organization Science, 15(2), 241-253.

Kim, W. G., Leong, J. K., \& Lee, Y. K. (2005). Effect of service orientation on job satisfaction, organizational commitment, and intention of leaving in a casual dining chain restaurant. International Journal of Hospitality Management, 24(2), 171-193.

Kim, S. (2006). Public service motivation and organizational citizenship behavior in Korea. International journal of manpower, 27(8), 722-740.

Kirkman, B. L., \& Shapiro, D. L. (2001). The impact of cultural values on job satisfaction and organizational commitment in self-managing work teams: The mediating role of employee resistance. Academy of Management Journal, 44(3), 557-569.

Khalid, S. A., Kassim, K. M., Ismail, M., Noor, A. N. M., Rahman, N. A., \& Zain, R. S. (2009). Emotional intelligence and organizational citizenship behavior as antecedents of students' deviance. International Journal of Business and Management, 4(7), P117.

Kondratuk, T. B., Hausdorf, P. A., Korabik, K., \& Rosin, H. M. (2004). Linking career mobility with corporate loyalty: how does job change relate to organizational commitment?. Journal of Vocational Behavior, 65(2), 332-349.

Jain, A. K. (2009). Exploring the relative relevance of organizational citizenship behavior and emotional intelligence. Journal of the Indian Academy of Applied Psychology, 35(1), 87-97.

Meyer, J. P., \& Allen, N. J. (1991). A three-component conceptualization of organizational commitment. Human Resource Management Review, 1(1), 61-89.

Paine, J. B., \& Organ, D. W. (2000). The cultural matrix of organizational citizenship behavior: Some preliminary conceptual and empirical observations.Human resource management review, 10(1), 45-59.

Podsakoff, P. M., MacKenzie, S. B., Paine, J. B., \& Bachrach, D. G. (2000). Organizational citizenship behaviors: A critical review of the theoretical and empirical literature and suggestions for future research. Journal of management,26(3), 513-563. 